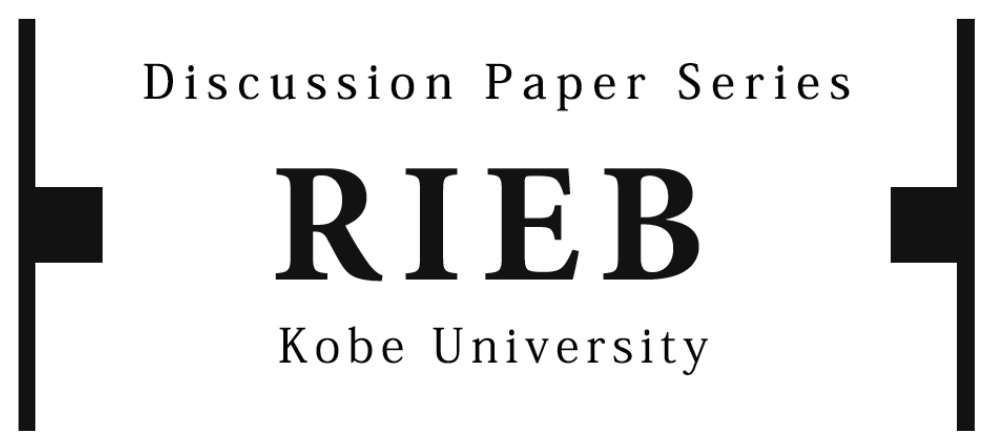

DP2016-31

\title{
Job Satisfaction of Returnees to Japan*
}

\author{
Lara MAKOWSKI \\ Ralf BEBENROTH
}

September 28, 2016

* The Discussion Papers are a series of research papers in their draft form, circulated to encourage discussion and comment. Citation and use of such a paper should take account of its provisional character. In some cases, a written consent of the author may be required.

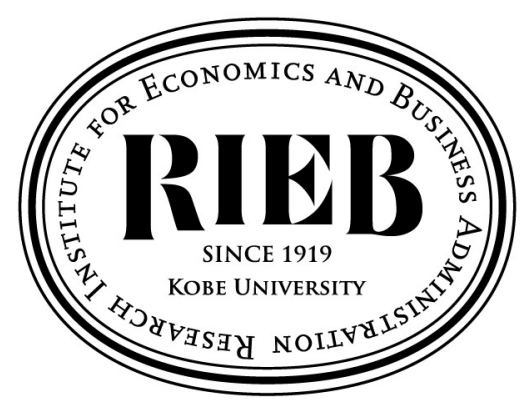

Research Institute for Economics and Business Administration

Kobe University

2-1 Rokkodai, Nada, Kobe 657-8501 JAPAN 
Job Satisfaction of Returnees to Japan ${ }^{1,2}$

\author{
Lara Makowski \\ $\mathrm{PhD}$ Student at Kobe University \\ Graduate School of Business Administration \\ 657-8501 Kobe-shi, Nada-ku, Rokko-dai 2-1 \\ lara.makowski@outlook.com \\ Japan
}

Prof. Dr. Ralf Bebenroth

Kobe University

Research Institute for Economics and Business Administration

657-8501 Kobe-shi, Nada-ku, Rokko-dai 2-1

mailbox@bebenroth.eu

Japan

\begin{abstract}
:
We investigate how Japanese returnees' job satisfaction is influenced by their organizational identification, their cultural openness and the degree of the 'Japaneseness' of the business system in their firms. On the tenets of social identity and cultural fit theory, we find that stronger identified Japanese returnees are more job satisfied. Furthermore, the degree of "Japaneseness" of the business system is negatively related to the job satisfaction of returnees, indicating that firms with a rather Western business system have more job satisfied returnees in their workforce. Also, even though we do not find any direct relationship between cultural openness and job satisfaction, we receive weak support, that cultural openness moderates the influence of the Japanese business system on a returnee's job satisfaction. That is, the group of culturally more open returnees has a higher job satisfaction when working in a rather Japanese business system.
\end{abstract}




\section{Introduction}

In the urge of globalization, multinational corporations are becoming increasingly aware of the importance of a global workforce, consisting of employees with international experience (Bossard and Peterson, 2005; Yeung and Olds, 2000). In order to globalize a firm, especially the expatriation of headquarter managers to foreign affiliates was seen as a smart way to bridge challenges and has therefore been a popular topic in academic research for many years (Edstroem and Galbraith, 1977; Bhaskar-Shrinivas et al., 2005; Hechanova et al., 2003; Baruch, Altman and Tung, 2016).

Besides expatriation, new forms of employment types are increasingly discussed regarding the internationalization of a firm (Bebenroth and Pascha 2011). In Japan, bigger firms, like e.g. Toyota, nowadays send large numbers of their young employees to overseas' assignments for short term trainings and career development (Fumoto, 2011). Another way to internationalize a firm is to employ "returnees", individuals with work experience abroad that already have returned to their country of origin. This phenomenon is a typical one for Asian and Pacific Rim countries, where many number of individuals decide to go abroad to gain overseas' experiences before eventually returning home. Tung (2006) coined the term "ex-host country nationals referring to returned Chinese with a long duration abroad (see also Tung 2016, Tung and Verbeke, 2010). The phenomenon of returnees exist also in countries like Australia or New Zealand. Several studies found evidence that individuals returned to New Zealand gained not only many valuable experiences through their stay abroad, but were also able to use their knowledge effectively upon return (Tharenou, 2009; Inkson et al., 2004).

In contrast to New Zealand and Australia, Japan has its own specific characteristics. Japan's companies usually have a closed business system with a high context culture, where not only performance but also personnel relationships are a crucial matter. Also, foreign language skills, especially English are highly valued assets for Japanese returnees. Those skills tend to count higher than (Non-English) language skills of returnees in New Zealand or Australia. To give an example, Japanese returnees with medium English skills are likely to outperform local Non-Japanese at the (Japanese) headquarters as their mother tongue is Japanese and they can adjust to the Japanese firm culture more easily than Non-Japanese. To take another example, also a Chinese with some living and working experience in Australia (e.g. for two years) would outperform an Australian after returning to the Chinese headquarters. The reason is that Chinese language for an Australian is much more difficult to master than English 
for an Asian. That means for Japanese firms, being in the need to hire international managers at the headquarters, they prefer to employ rather Japanese with medium English skills than a Non-Japanese English mother tongue speaker with medium Japanese language skills. Furthermore, especially for Japan the understanding of the business culture needs mention. Besides language issues, local Japanese managers at the headquarters with a low command of English language skills would not trust the new Non-Japanese because they are not able to fully understand them.

There is also practical evidence by Japanese head hunters stating that the highest valued talents on the Japanese job market consist of Japanese returnees with experience in a given area. They are treated as so called A-class hires. Locally hired Non-Japanese are treated as B-class hires, and regular Japanese with merely low English capability would be considered as C-class hires (Interview with Japanese head hunter). However, to the authors' knowledge, there is so far no published research available on Japanese returnees investigating their importance to the Japanese management praxis. This situation motivated the authors to conduct a country level study on Japanese returnees, testing which factors influence their job satisfaction.

This paper makes three contributions to the literature. First, we observe organizational identification to investigate the job satisfaction levels of the increasing number of Japanese returnees. Second, we integrate returnees' cultural openness as a moderator into this research, and third, we focus on the Japanese business system.

We contribute to the social identity theory and cultural fit perspective in finding that organizational identification is also an important aspect for the specific group of returnees that influences their job satisfaction. This is an intriguing finding as many returnees can be considered to have a rather short term stay at the firms. Also, job satisfied Japanese returnees prefer to work in a rather Western management system. The particular group of culturally open returnees however, are happier in a business environment that is more Japanese.

We proceed as follows. Part 2 discusses the theoretical underpinning, followed by a description of the Japanese culture and the Japanese business system. Part 4 states the hypotheses, followed by the method and the results. The discussion is brought in part 7 followed by a closing section.

\section{Theoretical part}

\subsection{Returnees in contrast to other forms}

The most dominating topic in the academic literature about transfer of managers remains the expatriate research (Edstroem and Galbraith, 1977; Bhaskar-Shrinivas et 
al., 2005; Hechanova et al., 2003; Baruch, Altman and Tung, 2016; Takeuchi, 2010). In contrast to expatriate research, repatriate issues received less attention (Chiang et al., 2015; Suutari and Brewster, 2003, Hyder and Lövblad, 2007). The reason for the under researched repatriate topic is, that repatriates are assumed to know and understand the culture and habits of their home countries as well as common work practices in the business field. However, recent studies suggest that repatriation might be at least as problematic as expatriation, as many repatriates have to deal with the so called 'reverse culture shock' (Kraimer, et al., 2012; Hyder \& Lövblad, 2007; Bossard Peterson, 2005; Morgan et al. 2004).

In order to better understand expatriation and repatriation and to better manage the difficulties that come along exchanging headquarter employees, Baruch, Altman and Tung (2016) proposed an expatriation and repatriation framework that enables a global career to be embedded in a wider social-economic environment of globalization. This concept can be seen through the lens of a career ecosystem and replies to an increasing number of both employers and employees still reporting their frustration from the process of repatriation (Paik et al. 2002).

Japanese firms with the aim to become more international used to rely heavily on the practice of expatriations. Recently; however, also in Japan there are several other options in addition to expatriation and repatriation. First, local Japanese employees can be trained to become more international, at least to be able to communicate in English.

Second, foreigners can be employed at a Japanese headquarters to increase internationalization. Different to classic so called organizational expatriates (OEs), which are sent by the headquarters, there is a stream of research focusing on 'self-initiated expatriates' (SIEs). Employees in these cases are not send by the headquarters but went by their own will to other countries (Stahl, Miller and Tung, 2002; Peltokorpi and Froese 2009). Despotovic et al. (2016) emphasizes a lack of research regarding SIEs, especially of non-Americans and non-Europeans, even though they represent a growing part of the international talent pool. In contrast to other individuals coming home, returned SIEs with working experience abroad can easily be employed as soon as they are back in the country. Other studies call them ex-host country nationals (Tung, 2006 and 2016). We call those returned Japanese SIEs 'returnees'. This study focuses on the increasing demand of returnees in Pacific Rim countries. The returnees meet the conditions for A-class hires; being individuals who independently left their home country for a longer time period abroad and gained working and living experiences. In this research, their job satisfaction will be investigated. 
In contrast to repatriates, returnees have their specific characteristics. They do not have headquarters to return to and also, different to repatriates (Chiang, Esch, Birtch, and Shaffer, 2015), returnees do not have any 'expatriate experience' at a given foreign subsidiary of a specific headquarters. They come home to their country of origin not because a headquarters wants them to come back, or because their expatriation time abroad has expired. Returnees return to their country for other reasons. It might be financially driven. Also there exist rare cases where the reason is being head-hunted by Japanese intermediaries to continue their career in Japan, A more common reason is that returnees' expect to simply feel better being in their home country again. Family issues could also be responsible for the return to their country of origin, e.g. to Japan where elderly family members need to be taken care of by their children. In the case of family reasons and without a fixed workplace to return to, returnees are in a weak position to negotiate and would in these cases even agree to take job offers for low paid jobs or for jobs they are overqualified for. It can be stated that most often returnees return rather unplanned. They come back to their home country to find themselves without orientation and are unexpectedly rather lost in the Japanese business landscape.

Furthermore, it is also likely that Japanese returnees have faced trouble abroad as e.g. their English was not as fluent as compared to their native peers in English speaking countries like Australia or in the US. Back home in Japan, their English abilities are now likely to easily outperform those of other Japanese colleagues. Returnees now may gain respect by other Japanese colleagues as their skills and experiences can help Japanese firms to bridge with international matters. Nevertheless, based on the previously stated reasons, it can be expected that returnees face a different and arguably more difficult re-adjustment to and re-integration into their home working environment than e.g. organizational repatriates.

\subsection{Social identity theory}

Social identity theory in its meaning claims that every human being is defined by social relationships (Cho, et al., 2014; Ashforth \& Mael, 1989; Van Knippenberg et al, 2007). The theory implies that an individual sees and defines him/herself to a certain extent or even completely as a part of a structured society, through group membership, or by subscribing to the values and meanings of a group, a society or an organization (Stets \& Burke, 2000). Considering an organization as a social group, employees generally tend to extract their social identities from their group of co-workers, age, gender, profession and the organization itself (Ashforth \& Mael, 1989; Johnson et al., 
2006). It has been understood for some time that organizational identification is one of the most important tools helping to understand an employee's behavior at the workplace and his/her attitudes towards the work (Van Knippenberg et al, 2007; Ashforth \& Mael, 1989). Furthermore, it was found in numerous studies that organizational identification correlates with several other constructs in an organization, such as job involvement, turnover, work absence and job satisfaction (Mael \& Ashforth, 1995; Riketta, 2005; Van Knippenberg et al, 2007).

Grounded on social identity theory to explain job satisfaction of returnees, we discuss identification, job satisfaction, cultural openness and the country business system in our analyses of Japanese returnees. Organizational identification was defined by Mael and Ashforth as "perception of oneness with or belongingness to an organization, where the individual defines him- $^{-}$or herself in terms of the organizations(s) in which he or she is a member" (1992, p. 104). Organizational identification often is embedded in the social identity theory, originated by the work of Tajfel and Turner (1979). Organizational identification measures in-group versus out-group orientation, where in -group members' benefit accumulates by establishing a strengthened relationship. The variable job satisfaction is defined by Locke in two influential essays. We apply the definition from the 1969 essay, as: (Job satisfaction is the) "pleasurable emotional state resulting from the appraisal of one's job as achieving or facilitating one's job values. In contrast, job dissatisfaction is the unpleasurable emotional state resulting from the appraisal of one's job as frustrating or blocking the attainment of one's values" (Locke, 1969, p. 317). In all, we assume that more job satisfied returnees do a better job at the given firm.

Cultural Openness refers to the degree to which an individual is open to different cultures. It is based on an individual's degree of an open mind and includes a person's degree to respect and/or adapt to other cultures and situations in general. This open mindedness includes customs, beliefs and values against that of people from different countries (Bebenroth \& Ismail, 2014). Cultural Openness also relates to the sociocultural adaptation, proposed by Searle and Ward (1990), describing the ability to 'fit in to' or to interact with foreign cultures. This naturally includes the ability to adapt to different firm cultures (Black et al., 1992). Cultural openness, as the extent to which employees are open to other situations or cultures, is based on the person-environment (P-E) fit perspective. This implies that individuals have to be suitable for the respective environments. It depends on the individual whether there is a 'fit' or a 'misfit'. A person-environment fit can be seen as a match of individuals' to environmental characteristics (P-E-Fit). P-E Fit has been studied on the improvement of HR related 
factors. Oakman and Wells (2016) analyze the effect of P-E fit for life time working durations, aiming to improve the retention of an elderly workforce on a sample in Australia. Fit in a closer sense is thereby not seen as to have similarities among the two, but rather as to have complementary items (Kristof-Brown et al., 2005). The cultural incompatibility or misfit is often seen as a reason for failures.

This theory was also applied to the M\&A field (Bauer and Matzler, 2014) coming into play at some studies examining cross border M\&A with cultural differences (Stahl and Voigt, 2008). Literature argues that cultural differences rather negatively affect a post-merger integration process. Also, it is stated that national cultural differences are stronger than organizational (firm) cultural differences to impact sociocultural integration (Bauer and Matzler, 2014). Chiang et al. (2015) introduced the cultural 'fit/ misfit' theory to repatriation research. According to the authors, repatriation can be seen as the repatriates' progress to 'fit' back into their home country and home culture. They developed a multi-level conceptual framework of 'fit' to better understand the progress of repatriation. 'Fit' was referred to as the amount to which repatriates' expectations on and perceptions of work- and nonwork-related factors matched with the actual, 'real' environment (Kristof-Brown et al., 2005). We study returnees' cultural fit to their job satisfaction in Japan.

\section{Japanese Business System}

Starting in the $1970^{\text {th }}$, the Japanese business system as a model was seen as very successful. The high respect Japanese firms had gained from other nations continued until the so called bubble period of the late $80^{\text {th }}$. Japanese business and management until the early 90s was a hot topic not only in Japan but much more in other developed countries and had been the subject of several studies conducted by scholars from all over the world. The question was "what could be learned from Japan?" (Hall \& Leidecker, 1981; Endo et al., 2014).

Japanese Business System was described by Blahova \& Zeleny as a management and business system of fundamental processes where firms are embedded to assure that objectives are achieved (Blahova \& Zeleny, 2013). The Japanese business system was predominantly studied comparatively of how organizations and management systems of Japanese companies differed from corresponding practices in the West (Hall \& Leidecker, 1981; Bowen, 1977). Researchers still today describe the Japanese business system as consistent of three main characteristics: lifetime employment with a seniority based pay and promotion system, consensus decision making, and job rotation (Hatvany \& Pucik, 1981). In addition, values of the Japanese culture consist of, among others, a 
preference of collectivism over individualism, indicating a lower importance of individual contribution and valuing the 'we' more than the 'I' (Hofstede, 1984). The Japanese system is also associated with a tough working life and not seldom described as a work environment linked to a poor work-life balance, where long working hours are still the norm. Also, unpaid overtime work is widely spread and vacation for more than a week at a time is considered to be an exception. Consequentially, there are high on-the-job stress levels and even high suicide rates are reported in Japanese firms (North and Weathers, 2007).

Regarding the employment system, Japanese firms not only rely on their regular employed as the major (first) workforce but also, second, on dispatched or temporary "lend" employees by a so called "haken" (dispatched) firm. A third group consists of part timers, where the meaning is different to the Western understanding. Japanese part timers often start early in the morning until the evening five days a week, doing the same work regular workers conduct. However, they just do not receive a long term contract. Also, no bonus or any other benefits are offered to them. This can be described as a way for many Japanese firms to compete in blue collar work against international competitors. In terms of internalization, many Japanese firms face hardship. Japanese managers hardly want to leave the country. When being hired by a firm, Japanese employees intend to obtain international exposure but within their firms, agreeing on being send abroad as expatriates. As soon as they have a family; however, they do not want to leave the country anymore. Also, expatriation is a very cost intensive issue for MNCs.

As another issue, the language situation in Japanese firms needs to be mentioned. Even as the world's third biggest economy in terms of GDP, the English language is only spoken by a few. Put different, compared to other countries, Japan can be considered as rather underdeveloped in the use of foreign languages (Tsuneyoshi, 2005). Therefore, companies face difficulties to find English speaking staff and many Japanese firms suffer due to this shortage as they cannot bring their full potential to the (world) market (Tsuneyoshi, 2005). Because of a shortage of international talents, multinational corporations in Japan are more than ever in high demand of English speaking employees. In this, these people should not only be able to communicate in a foreign language (preferably English) but should further understand people from foreign countries being able to deal with international matters.

Also, Tenzer and Pudelko (2013) have shown that the use of a foreign language can be a barrier for employees at the firms. Problems to articulate can cause negative emotions to employees, which in turn can negatively influence the interpersonal relationships 
among co-workers and team members. That should count for Japan more than to other countries. It is to say, even if a few Japanese multinational firms put a high importance to their English-language proficiency scores, the English level on average spoken in Japan is not comparable with firms in other countries. It is to be mentioned, however, that in exceptional Japanese firms where English is used as the company language, language skills become an important criterion for recruitment and promotion. In this sense, changes in Japanese recruitment and employment systems can be considered as a fruitful ground to research language issues (Yamao and Sekiguchi, 2015).

\section{Hypotheses Developments}

\subsection{Effect of Organizational Identification on Job Satisfaction}

The job satisfaction theory suggests that satisfaction of employees rests on two main pillars, on the one hand on the value of work and on the other hand on rewards received at the job (Kallerberg in 1977). Research with expatriates shows that job, task and organizational factors increase job satisfaction and decrease tendency of turnovers (Shaffer and Harrison, 1998; Nauman 1993; Van Knippenberg and Schippers, 2007). Furthermore, Kristof-Brown et al. (2005) found that higher organizational identified expatriates have a higher person-organization fit, which has positive influences on the individual's job satisfaction. In accordance with these empirical findings in the expatriate literature, we assume that higher organizational identified returnees should be more job satisfied. That means, even if returnees often come coincidently to a given firm and may not stay for a long time, or even are treated differently compared to other regular employees, their identification should also influence their job satisfaction. We therefore state the following hypothesis:

H1: A higher organizational identification of returnees to their firms leads to higher job satisfaction.

\subsection{Effect of Japanese Business System on Job Satisfaction}

In order to examine whether the Japanese business system has an effect on a returnee's job satisfaction, we apply a classic Likert scale (from 1 to 5 ) to divide firms in more Japanese business system oriented (1) and in the ones that are more westernized (5). We assume that returnees who have experienced a western business system should value it highly, e.g. a fast decision making process and an open discussion should be 
appreciated. Besides a performance based pay system, instead of a lifetime employment contract with a seniority based pay, should be valued highly. Also, returnees should prefer a more flexible instead of a consensus making decision making process. We further assume that a work-life balance should be valued highly together with a cut of unpaid overtime and an increase in vacation. Firms with a Western style management have these characteristics in contrast to Japanese business system firms who rather lack them. Therefore, returnees in a company with a high level of 'Japaneseness' in their business system should be less job satisfied. Our hypothesis; therefore, is:

H 2: The more Japanese the company's business system, the less satisfied are returnees.

\subsection{Effect of Cultural Openness on Job Satisfaction}

Returnees should not be treated as a homogeneous group. When staying abroad, some of them may be exposed to other cultures, but others may not. Prior research suggests that culturally open individuals are more flexible and adapt more easily to different situations (Shi \& Franklin, 2014). In contrast, culturally rather closed individuals feel uncomfortable in unfamiliar situations. As Japanese tend to stay in groups (of their own), this phenomenon of segregation, being in another country but spending most of the time with fellow natives applies for the Japanese culture more than for others. In this, more culturally open Japanese individuals should be more helpful to bridge international matters to the firm's needs. These employees are having a decisive advantage in understanding other cultures and also may to a much higher extent be able to help the Japanese headquarters with their actions. In contrast, cultural closed colleagues lack this ability. Even if they have spent time abroad (in rather closed circles of Japanese), they can hardly be of any help to the headquarters' intentions and efforts. Culturally closed returnees; therefore, should rather be dissatisfied with their jobs. To sum up, we assume that culturally more open returnees coming back to Japan are positively influenced to their job satisfaction.

H3: The more culturally open the returnees, the higher their job satisfaction

\subsection{Moderating effect of Cultural Openness}

As stated above, Japanese returnees are expected to value the Western business system higher than the Japanese business system. On average, they should prefer to work for a 
Western style firm. The reason is, it offers a more employee friendly environment which leads to a higher job satisfaction. However, for the small group of culturally open Japanese returnees, we have two contrasting thoughts leading us to believe that they behave differently to the "average" returnees. On the one hand, it is thinkable that culturally open returnees may be strictly rejecting to work at a firm which has the Japanese business system, as they experienced the Western model with a rather flexible job, a high job empowerment, independence and a performance based payment. In this sense, especially the group of cultural open returnees should appreciate the Western model to work in after having returned to Japan.

However, the opposite may also be thinkable for the group of culturally highly open returnees. As we assume that culturally more open returnees have a higher ability to adapt to different environments, it is thinkable that they are not only more open for Western thoughts and a Western working system, but they also may be open for the Japanese system. In this line of argumentation, one could assume that culturally more open returnees would rather be satisfied in a Japanese oriented business system environment. In other words, culturally open returnees experienced the foreign culture much more intensive than cultural rather closed counterparts. They may now appreciate their own (Japanese) culture more strongly after being back to their country. Therefore, we test a moderating influence of returnees' cultural openness to the Japanese business system on job satisfaction. Our two contrasting hypotheses state that the group of culturally more open returnees behave differently, that they are less / more job satisfied than other returnees when working in a Japanese business system. We propose the two contrasting hypotheses:

$\mathrm{H} 4 \mathrm{a}$ : The group of culturally open returnees is less job satisfied in companies with a high level of 'Japaneseness' in their business system.

H4 b: The group of culturally open returnees is more job satisfied in companies with a high level of 'Japaneseness' in their business system.

\section{Method and Data Collection}

\subsection{Method}

This section explains the measurement of the constructs, the model and the data collection. Organizational identification was measured with eight items, based on the Organizational Identification Questionnaire by Cheney (1983) but adapted to meet the 
profile of returnees. One of the questions was: "If a story in the media criticizes the firm], I would feel embarrassed". The construct cultural openness was constructed to measure to what extent a returnee's level of cultural openness and therefore open-mindedness influences the returnee's job satisfaction. Cultural openness was derived from Van Dyne et al. (2008) and was measured with five items. One of the questions was: "I am confident that I can socialize with locals in a culture that is unfamiliar to me".

The construct of Japanese business system measured the extent of 'Japaneseness' of a given firm where the returnee worked. As for the Likert scale, 1 refers to "very Japanese" and 5 refers to "very westernized". In this, we did not just categorize the firms in Western or Japanese business system given solely their national affiliations. For example, a Japan based foreign affiliate could easily be counted as a Western firm, while a local Japanese firm could easily be counted as a firm having a Japanese business system. However, complexity arises as some of the Japanese firms behave indeed rather international. The two Japanese firms, Rakuten and Uniqulo, e.g. recently declared their company language to be English (Yamao and Sekiguchi, 2015). In contrast, some other foreign firms in Japan are having a long experience in the country and behave rather traditional and Japanese in their business style even if they are listed as a Western firm. An example would be Nestle from Switzerland, with its subsidiary located in Kobe, but operating rather traditional in their business behavior, having only a very few Non-Japanese in their Japanese headquarters and having a rather Japanese than Western style atmosphere in their office. The dependent variable "job satisfaction" was measured with eight items, a short form of the Minnesota Satisfaction Questionnaire (Igalens and Roussel, 1999), one of the questions, e.g., was: "I am satisfied with my job".

Model:

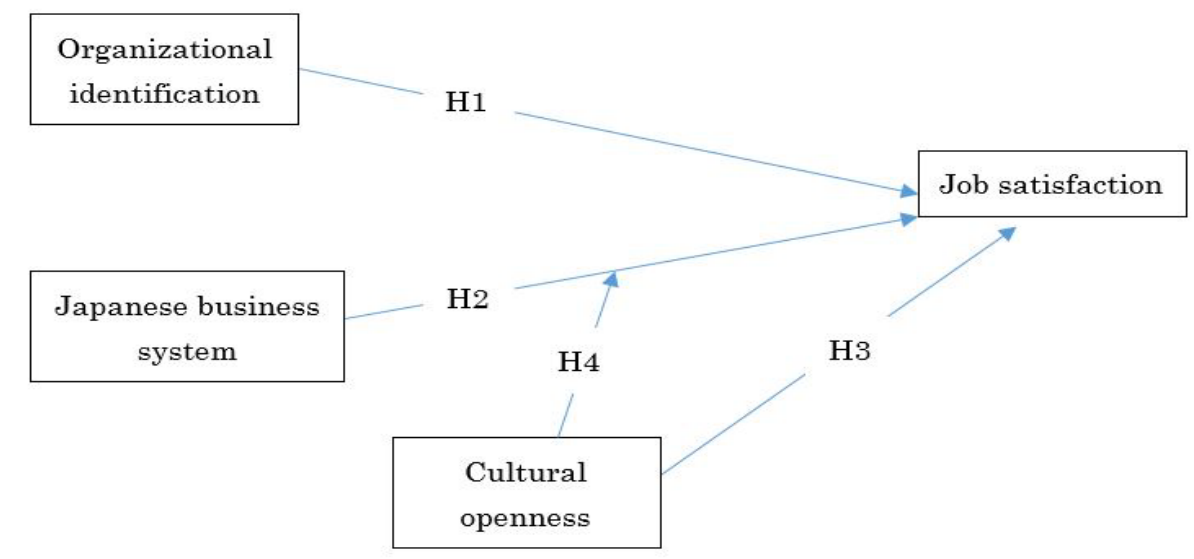




\subsection{Data Collection}

Japanese returnees' job satisfaction is analyzed in regard to their antecedents, such as organizational identification, their cultural openness and to the degree of 'Japaneseness' in the business at the company they work for. All respondents are Japanese nationals with both working experience abroad and in Japan. The data consists of 90 observations collected during a six-week period from October $7^{\text {th }} 2015$ to November $23^{\text {rd }} 2015$ with an online survey program. The questionnaire used in this study consists of 35 questions grouped into seven different categories. The first page consisted of a cover letter, explaining the questionnaire's purpose and stating the criteria that the authors had solely academic intentions and that the data were kept strongly confidential. Also, the authors mentioned to share the results of this study to the participants (on an anonymous basis).

\section{Results}

This study uses structural equation modeling (SEM) with the SmartPLS software (Ringle et al., 2005) to empirically test the above proposed four hypotheses. The use of PLS-SEM has increasingly gained popularity in the new millennium as a method for multivariate analyses in academic research (Hair et al., 2012; Moghaddam et al., 2015). PLS was chosen as an analysis tool for this study as PLS modelling is able to handle a small sample size. Furthermore, it is seen as convenient for studies that conduct prediction־oriented research (Henseler et at., 2009; Moghaddam et al., 2015).

Most of our constructs have reasonable internal consistency. Measured with Cronbach's Alpha, job satisfaction $=0.88$, organizational identification $=0.812$ and cultural openness $=0.863$. Only our self-constructed variable of Japanese business system has a surprisingly low Cronbach's Alpha loading with merely 0.448 (beneath 0.5). However, the AVE (average variance extracted) reaches with 0.483 almost at its recommended threshold of 0.5 , meaning that it explains almost $50 \%$ of its indicator variance (Table 2). We therefore decided to work with these constructs in the following analyses.

We evidence that on average, all of our constructs such as job satisfaction, organizational identification and cultural openness are all clearly above the middle of 3.0 (3.47; 3.45 and 3.98 respectively). That means, returnees of our sample are on average rather job satisfied, highly identified and (as we expected for returnees) culturally open minded. The low construct of the Japanese business system with 2.6 refers to more Japanese style than western style firms where our respondents come from (Table 3). 
In accordance with the social identity theory and the person-environment fit perspective, we tested the following hypotheses. $\mathrm{H} 1$ hypothesis stated that returnees with a higher level of organizational identification are the more job-satisfied employees. The structural equation modeling was able to confirm this hypothesis $(0.513,1 \%$ sign.) and therefore confirmed that returnees with a higher level of organizational identification are more job-satisfied. Also, it is to mention that the variance to explain job satisfaction with $51 \%$ is very high, meaning that identification has the biggest impact and explains half of the job satisfaction.

It was expected and hypothesized in $\mathrm{H} 2$, that the more 'Japanese' the business style is at the firm, the less job satisfied are the Japanese returnees. The structural equation modeling showed that Japanese business system indeed had a statistically significant and negative influence on job satisfaction ( $-0.227,5 \%$ sign.), therefore the hypothesis $\mathrm{H} 2$ was confirmed. H3 hypothesized that returnees with a higher level of cultural openness are the more job-satisfied employees. The structural equation modeling showed no statistically significant relation between cultural openness and job satisfaction and; therefore, H3 hypothesis could not be confirmed.

It was furthermore believed, that the more culturally open minded returnees are a specific group of interest behaving differently compared to other returnees. In our contrasting hypotheses, we stated that they adapt less (H4a) or more (H4b) to not only new cultures, but also to the work in their own Japanese business culture. That means for this special group, there are logical reasons to assume a negative / positive influence on job satisfaction in regard to the business system they work in. Our hypothesis H4b was weakly confirmed $(0.14 ; 10 \%$ sign.), that the group of job satisfied culturally more open returnees indeed rather prefers to work at a firm with a Japanese business system than with a Western style system.

\section{Interpretation and Discussion}

Based on the social identity theory and the cultural fit theory, we tested our hypotheses regarding Japanese returnees. The existing literature states that better identified employees are the more satisfied. We have evidence that this also applies to returnees, meaning that also Japanese returnees with a high level of organizational identification are more job-satisfied employees (Ashforth \& Mael, 1989; Riketta, 2005; Mael \& Ashforth, 1995). Japanese business system is proved to have a negative relationship with a returnee's job satisfaction. That means, returnees (on average) are more job satisfied when working in a rather Western business system. 
The result of having no direct relationship between culturally open and satisfied returnees is consistent with earlier research. In regard to the cultural openness of Japanese target firm employees after a cross border acquisition, e.g. also Bebenroth \& Ismail (2014) could not find evidence that more culturally open target employees were higher job satisfied. Furthermore, not the younger (as assumed in the research), but the senior employees of the target firm were culturally more open minded. However, the more open minded seniors turned out to be the less job satisfied employees. This study; therefore, also failed to confirm that culturally more open Japanese are more job satisfied.

Our research therefore suggests, that in order to increase the job satisfaction of returnees, the management of a company should reduce the 'Japaneseness' in their management system. In this, individual contribution has to be more valued (Hofstede, 1984) and wage should be based on personal contributions. The Japanese business system however typically follows a seniority based wage system. Not being rewarded for their individual contribution and efforts, therefore, may lead to a lower job satisfaction among returnees. For returnees, a work-life balance should be implemented and valued. The privilege of a work-life balance and more performance oriented pay (Craig, 2009) may also increase the returnees' happiness. This demand can hardly be fulfilled by the Japanese business system.

The variable cultural openness was used as a moderator in order to test if the degree of cultural openness moderates the relationship between Japanese business system and job satisfaction. Based on findings in the existent literature (Black et al., 1992; Shi \& Franklin, 2014) it was assumed that the group of culturally open returnees is a special group of interest and needs to be treated accordingly. We proposed two contrasting hypotheses; that more culturally open returnees are less / more job satisfied in their firms with a higher level of 'Japaneseness' in their business system than less culturally open returnees. There is weak statistical evidence that returnees with a higher ability to adapt and to 'fit in' to other cultures also better fit in when being back in their own culture. The structural equation modeling was able to confirm this hypothesis in regard to having the group of cultural open minded being more job satisfied at firms practicing the Japanese business system. The study therefore can confirm that returnees with a high level of cultural openness are more job satisfied in a rather Japanese business system.

This study makes the following theoretical contributions. Considering elements of social identity theory, we have evidence that the higher identified returnees are the more job satisfied. Also, even if cultural openness not directly affected job satisfaction, 
indirectly in relationship with the Japanese business system, we see that returnees normally prefer to work at a rather Western firm in Japan. That means, identification counts also for returnees as a very important aspect to their job satisfaction. Only in case of culturally highly open returnees, a rather Japanese business system was preferred. These findings also support the person-environment fit perspective, that returnees value the environment highly being back to Japan.

Additionally, this research offers practical implications. Higher identified returnees are more job satisfied, even if they may consider themselves rather as outsiders at the firm in Japan as they may not have a long duration at the firm. Also, they most probably did not start at the same time as with their peer colleagues from college. However, also for returnees, identification matters. Firms are advised to make returnees identified to the firm as soon and as much as possible to achieve a higher job satisfaction. Therefore, to increase a returnee's level of job identification, returnees should be treated as an important group, instead of giving them the feeling of not fully belonging to the center of the decision making at the firm. As returnees normally prefer to work at a rather Western firm, Japanese firms may use a separate Western style business concept for the returnees to allow them to have some benefits they would also receive at firms with a rather Western style of business. Only the group of cultural open returnees feels even better when working in a Japanese business system.

This study has its own limitations. It is in its nature cross sectional, meaning participants at the study were only contacted once. Therefore, we cannot be sure if e.g. identification influenced job satisfaction, or the other way around, that job satisfaction influenced identification. Also, the sample was taken out of personal contacts of the authors. There could be a bias in the sampling, as some of the participants introduced their friends to participate (with possibly similar attitudes about Japan and the Japanese business system). Furthermore, we asked about perceptions of returnees. There might be a bias as some participants might be rather negative in their nature not caused by the firm directly but by the trouble they face outside the firm. For example, the need to take care of family members as a reason could lead to the situation that returnees also have a negative attitude in regard to their firm. Also, our self-developed construct of Japanese business system needs to be refined in future research as the loadings were low, indicating that the respondents did not fully understand it. Future studies should consider reasons of returnees to lower the heterogeneity of this group. Also, participants were Japanese and responses could be biased because of cultural issues. For example, Westerners rather decide clearer in answering yes or no, while Japanese tend to be rather indifferent, meaning that Japanese answer more close to the 
middle.

Also, perceptions of returnees might differ according to their firm. In this, returnees at Western firms might be disappointed about how Japanese the business system is. While returnees at a Japanese firm might be positively surprised about how Westernized the Japanese business system is. That means, one group may be positively and the other group negatively exposed to its business style, even if both firms have the same.

\section{Closing}

We investigated returnees' job satisfaction and found evidence that mainly organizational identification contributes to a higher job satisfaction. That means, also for returnees who might not be at a firm for a long time, identification matters. Furthermore, the degree of the business system is an important factor for returnees' happiness with their jobs. On average, returnees prefer to work in a rather Western system and we have evidence that returnees are less satisfied at Japanese business system firms. However, we found that cultural openness moderated the effect of the Japanese business system on the returnee's job satisfaction; The group of cultural more open returnees is more job satisfied when working in a Japanese business system environment.

1 Major parts of this work were done by the second author at his stay at Harvard University in summer 2016. We thank EALS (East-Asian-Legal-Studies) for providing facilities.

2 Interviews were conducted by the first author with several returnees as well with so called head hunter firms in Osaka. 
References

Ashforth, B., \& Mael, F. (1989). Social Identity Theory and The Organization. The Academy of Management Review, 14(1), 20-39.

Baruch, Y., Altman, Y., \& Tung, R. L. (2016). Career Mobility in a Global Era: Advances in Managing Expatriation and Repatriation. The Academy of Management Annals, 10(1), 841-889.

Bauer, F., \& Matzler, K. (2014). Antecedents of M\&A success: The role of strategic complementarity, cultural fir, and degree and speed of integration. Strategic Management Journal, 35, 269-291.

Bebenroth, R., \& Ismail, M. (2014). Cultural Openness, Interpersonal Justice, and Job Satisfaction among Millennials and Seniors: Evidence from Japanese Target Employees following M \& A. Kokumin Keizai Zashi, 210(6), 29-47.

Bebenroth, R., \& Pascha, W. (2011). Agency concerns and resource endowment issues of strategic management staffing desicions among German subsidiaries in Japan. In: IHRM in Foreign Subsidiaries in Japan. Zeitschrift für Betriebswirtschaft (ZfB), 3(81), 5-25.

Bhaskar-Shrinivas, P., Harrison, D., Shaffer, M., \& Luk, D. (2005). Input-Based and Time-Based Models of International Adjustment: Meta-Analytic Evidence and Theoretical Extensions. Academy of Management Journal, 48(2), 257-281.

Black, J. S., Gregersen, H. B., \& Mendenhall, M. (1992). Global assignments: Successfully expatriating and repatriating international managers. San Fransisco: CA: Josey-Bas.

Blahova, M., \& Zeleny, M. (2013). Effective strategic action: Exploring synergy sources of European and Asian management systems. Human Systems Management, $32,155-170$

Bossard, A. B., \& Peterson, R. B. (2005). The repatriate experience as seen by American expatriates. Journal of World Business, 40(1), 9-28.

Bowen, W. (1977). Japanese Managers Tell How Their System Works. Fortune, 96, 126-132.

Cheney, G. (1983). On the various and changing meanings of organizational membership: A field study of organizational identification. Communication Monographs, 50(4), 342-362.

Chiang, F. T., Esch, E. V., Birtch, T. A., \& Shaffer, M. (forthcoming). The Consequences of Expatations: A Look at Possible Directions for Repatriation Research. Academy of Management.

Cho, B., Lee, D., \& Kim, K. (2014). How does Relative Depriviation influence Employee 
Intention to leave a merged Company? The ROle of Organizational Identification. Human Resource Management, 53(3), 421-443.

Craig, T. (2009). Live to Work or Work to Live? The Search for Work-life Balance in 21st Century Japan. Doshisha Society for the Study of Language and Culture, 12(2), 311-344.

Despotovic, W. V., Hutchings, K., \& McPhail, R. (2015). Cross-cultural self-preparation of Australian self-initiated expatriates for working and living in South Korea: 'Stumped like a bonsai: A show of what could have been'. Asia Pacific Journal of Human Resources, 53(2), 241-259.

Edström, A., \& Galbraith, J. R. (1977). Transfer of managers as a co-ordination and control strategy in multinational organizations. Administrative Science Quarterly, 22(2), 248-263.

Endo, T., Delbridge, R., \& Morris, J. (2014). Does Japan Still Matter? Past Tendencies and Future Opportunities in the Study of Japanese Firms. International Journal of Management Reviews.

Fumoto, S. (2011, April 20). Tenki mukaeta shukatsu, raibaru wa sekai-ju ni [Job application activities at the turning point. Rivals are from all around the world]. Retrieved from Nihon Keizai Shimbun: http://nikkei.com/

Hair, J. F., Sarstedt, M., Ringle, C. M., \& Mena, J. A. (2012). An assesment of the use of partial least squares structural equation modeling in marketing research. Journal of the Academy of Marketing Science, 40(3), 414-433.

Hall, J. L., \& Leidecker, J. K. (1981). Is Japanese-style management anything new? A comparison of Japanese-style management with U.S. participative models. Human Resource Management, 20(4), 14-21.

Hatvany, N., \& Pucik, V. (1981). An Integrated Management System: Lessons from the Japanese Experience. Academy of Management Review, 6(3), 496-480.

Hechanova, R., Beehr, T., \& Christiansen, N. (2003). Antecedents and Consequences of Employees' Adjustment to Overseas Assignment: A Meta-analytic Review. Applied Psychology, 52(2), 213-236.

Henseler, J., Ringle, C. M., \& Sinkovics, R. R. (2009). The Use of Partial Least Square Modeling in International Marketing. Advances in International Marketing, 20, 277-319.

Hofstede, G. (1984). The Cultural Relativity of the Quality of Life Concept. The Academy of Management Review, $9(3), 389$.

Hyder, A. S., \& Lövblad, M. (2007). The repatriation process - a realistic approach. Career Development International, 12(3), 264-281. 
Igalens, J., \& Roussel, P. (1999). A Study of the Relationships between Compensation Package, Work Motivation and Job Satisfaction. Journal of Organizational Behavior, 20(7), 1003-1025.

Inkson, K., Carr, S., Edwards, M., Hooks, J., Johnson, D., Thorn, K., \& Allfree, N. (2004). From brain drain to talent flow: Views of Kiwi expatriates. University of Auckland Business Review, 6(2), 29-39.

Johnson, M., Morgeson, F., Ilgen, D., Meyer, C., \& Lloyd, J. (2006). Multiple professional identities: Examining differences in identification across work-related targets. Journal of Applied Psychology, 91(2), 498-506.

Kallerberg, A. L. (1977). Work values and job rewards: a theory of job satisfaction. American Sociological Review , 42, 124-143.

Kraimer, M. L., Shaffer, M. A., Harrison, D. A., \& Ren, H. (2012). No Place like Home? An Identity Strain Perspective on Repatriate Turnover. Academy of Management Journal, 55(2), 399-420.

Kristof-Brown, A. L., Zimmerman, R. D., \& Johnson, E. C. (2005). Consequences of individual's fit at work: A meta-analysis of person-job, person-organization, person-group, and person-supervisor fit. Personnel Psychology, 58, 281-342.

Locke, E. A. (1969). What is Job Satisfaction? Organizational Behaviour and Human Performance. 4, 309-336.

Mael, F., \& Ashforth, B. (1995). Loyal From Day One: Organizational Identification, and Turnover among Newcomers. Personnel Psychology, 48(2), 309-333.

Mael, F., \& Ashforth, B. E. (1992). Alumni and their Alma Mater: A Partial Test of the Reformulated Model of Organizational Identification. Journal of Organizational Behaviour, 103-123.

Moghaddam, H. A., Rezaei, S., \& Amin, M. (2015). Examining job seekers' perception and behavioural intention toward online recruitment: a PLS path modelling approach. Journal for Global Business Advancement, 8(3), 305-325.

Morgan, L. O., Nie, W., \& Young, S. T. (2004). Operational factors as determinants of expatriate and repatriate success. International Journal of Operations \& Production Management, 24(12), 1247-68.

Naumann, E. (1993). Organizational predictors of expatriate job satisfaction. Journal of International Business Studies, 24(1), 61-80.

North, S., \& Weathers, C. (2007). Asia Times Online. Retrieved 12 19, 2015, from http://www.atimes.com/atimes/Japan/IA06Dh01.html

Oakman, J., \& Wells, Y. (2016). Working longer: What is the relationship between person - environment fit and retirement intentions? . Asia Pacific Journal of 
Human Resources, 54(2), 207-229.

Paik, Y., Segaud, B., \& Malinowski, C. (2002). How to improve repatriation management: are motivations and expectations congruent between the company and expatriates . International Journal of Manpower, 23(7), 635-648.

Peltokorpi, V., \& Froese, F. J. (2009). Organizational Expatriates and Self-Initiated Expatriates: Who Adjusts Better to Work and Life in Japan? International Journal of Human Resource Management, 20(5), 1095-1111.

Riketta, M. (2005). Organizational identification: A meta-analysis. Journal of Vocational Behavior, 66(2), 358-384.

Ringle, C. M., Wende, S., \& Will, A. (2005). SmartPLS 2.0. www.smartpls.de.

Searle, W., \& Ward, C. (1990). The prediction of psychological and sociocultural adjustment during cross-cultural transitions. International Journal of Intercultural Relations, 14, 449-464.

Shaffer , M. A., \& Harrison, D. A. (1998). Expatriates' psychological withdrawal from international assignments: Work, non-work, and family influences. Personnel Psychology, 51(1), 87-118.

Shi, X., \& Franklin, P. (2014). Business expatriates' cross-cultural adaptation and their job performance. Asia Pacific Journal of Human Resources, 52, 193-214.

Smith, P., Kendall, L., \& Hulin, C. (1969). The measurement of satisfaction in work and retirement. Chicago, Ill.: Rand McNally.

Stahl, G. K., \& Voigt, A. (2008). Do cultural differences matter in mergers and aquisitions? A tentative model and examination. Organizational Science, 19(1), 160-176.

Stahl, G. K., Miller, E. L., \& Tung, R. L. (2002). Toward the boundaryless career: A closer look at the expatriate career concept and the perceived implications of an international assignment. Journal of World Business, 37(3): 1-12.

Stets, J., \& Burke, P. (2000). Identity Theory and Social Identity Theory. Social Psychology Quarterly, 63(3), 224.

Suutari, V., \& Brewster, C. (2003). Repatriation: emperical evidence from a longitudal study of careers and expectations among Finish expatriates. The International Journal of Human Resource Management, 14(7), 1132-51.

Tajfel, H., \& Turner, J. C. (1979). An Integrative Theory of Intergroup Conflict. The Social Psychology of Intergroup Relations. 33(47).

Takeuchi, R. (2010). A Critical Review of Expatriate Adjustment Research Through a Multiple Stakeholder View: Progress, Emerging Trends, and Prospects. Journal of Management, 36(4), 1040-1064. 
Tenzer, H., \& Pudelko, M. (2013). Leading across language barriers: Strategies to mitigate negative language-induced emotions in MNCs. Retrieved July 2015, from Academy of Management Proceedings: 12852: http://proceedings.aom.org/content/2013/1/12852.short

Tharenou, P. (2009). Self-initiated international careers: Gender differences and career outcomes. In S. G. Baugh, \& S. E. Sullivan (Eds.), Maintaining focus, energy and options over the career (pp. 197-226). Charlotte, NC: Information Age Publishing.

Tsuneyoshi, R. (2005). Internationalization strategies in Japan - The dilemmas and possibilities of study abroad programs using English. Journal of Research in International Education, 4(1), 65-86.

Tung, R.L. (2016). New perspectives on human resource management in a global context. Journal of World Business 51 (2016) 142-152

Tung, R. L. (2006). The use of ex-host country nationals in international assignments: A source of competitive advantage or disadvantage? Keynote speaker at the 26th International Congress of Applied Psychology.

Tung, R. L., \& Verbeke, A. (2010). Beyond Hofstede and GLOBE: Improving the quality of cross-cultural research. Journal of International Business Studies, 41(8): 1259-1274.

Van Dyne, L., Ang, S., \& Koh, C. (2008). Development and validation of the CQS. In S. Ang, \& L. Van Dyne, Handbook of Advances in Culture \& Psychology (pp. 16-38). New York: M. E. Sharpe.

Van Knippenberg, D., \& Schippers, M. C. (2007). Work Group Diversity. Annual Review of Psychology, 58, 515-541.

Wanberg, C. R., \& Banas, J. T. (2000). Predictors and outcomes of openness to changes in a reorganizing workplace. Journal of Applied Psychology, 85(1), 132-142.

Yamao, S., \& Sekiguchi, T. (2015). Employee commitment to corporate globalization: The role of English language proficiency and human resource practices. Journal of World Business, 50(1), 168-179.

Yeung, H. W.-C., \& Olds, K. (2000). Globalization of Chinese Business Firms. London: Palgrave McMillan. 
Table 1: (Data of the study) Latent Variables, Indicators and Questionnaire Items

\begin{tabular}{|c|c|c|}
\hline Latent & Indicato & Questionnaire items \\
\hline $\begin{array}{l}\text { Job } \\
\text { Satis-facti }\end{array}$ & SATa & $\begin{array}{l}\text { I am satisfied with... } \\
\text {... the company I work for }\end{array}$ \\
\hline on & $\mathrm{SATb}$ & ... my job security at the company \\
\hline & SATc & ... the overall communication within the company \\
\hline & SATd & ... the facilities provided by the company \\
\hline & SATe & ... my job \\
\hline & SATf & ... my salary in the company \\
\hline & SATg & ... the promotion opportunities in the company \\
\hline & SATh & ... the training \& development provided by the company \\
\hline Organi-za & IDa & When I talk about my firm, I usually say 'we' rather than 'I' \\
\hline tional & $\mathrm{IDb}$ & My firm's success is my success \\
\hline Identifi-ca & IDc & When someone praises my firm, it feels like a personal compliment \\
\hline tion & IDd & If a story in the media criticizes my firm, I would feel embarrassed \\
\hline & IDe & When someone criticizes my firm, it feels like a personal insult \\
\hline & IDf & I am very interested in what others think about my firm \\
\hline & IDg & $\begin{array}{l}\text { I feel employees with and without international experie3nce are } \\
\text { treated equally }\end{array}$ \\
\hline & $\mathrm{IDh}$ & I feel out of place at my company (reciprocal) \\
\hline $\begin{array}{l}\text { Japanese } \\
\text { Business }\end{array}$ & JBSa & $\begin{array}{l}\text { At my firm ... } \\
\ldots . \text { promotion and salary raise are seniority based }\end{array}$ \\
\hline System & $\mathrm{JBSb}$ & $\begin{array}{l}\text {... individual contributions are regarded as important } \\
\text { (reciprocal) }\end{array}$ \\
\hline & JBSc & ... work-life-balance is highly values (reciprocal) \\
\hline Cultural & CULTa & I enjoy traveling to foreign countries \\
\hline Openness & CULTb & I enjoy interacting with people from different cultures \\
\hline & CULTc & I am comfortable in communicating in a foreign language \\
\hline & CULTd & $\begin{array}{l}\text { I am confident that I can socialize with locals in a culture that is } \\
\text { unfamiliar to me }\end{array}$ \\
\hline & CULTe & $\begin{array}{l}\text { I am sure I can deal with the stress of adjusting to a culture that is } \\
\text { new to me }\end{array}$ \\
\hline & CULTf & I enjoy living in cultures that are unfamiliar to me \\
\hline
\end{tabular}


Table 2: Measurement model

\begin{tabular}{|c|c|c|c|c|}
\hline Construct & Indicator & Loading & Cronbach's a & AVE \\
\hline \multirow[t]{8}{*}{ Job Satisfaction } & SATa & 19.913 & \multirow{8}{*}{0.880} & \multirow{8}{*}{0.547} \\
\hline & $\mathrm{SATb}$ & 13.764 & & \\
\hline & SATc & 13.002 & & \\
\hline & SATd & 9.473 & & \\
\hline & SATe & 18.191 & & \\
\hline & SATf & 9.247 & & \\
\hline & SATg & 7.157 & & \\
\hline & SATh & 6.978 & & \\
\hline \multirow{8}{*}{$\begin{array}{l}\text { Organizational } \\
\text { Identification }\end{array}$} & $\mathrm{IDa}$ & 6.814 & \multirow{8}{*}{0.812} & \multirow{8}{*}{0.450} \\
\hline & $\mathrm{IDb}$ & 8.785 & & \\
\hline & IDc & 33.812 & & \\
\hline & IDd & 10.530 & & \\
\hline & IDe & 9.430 & & \\
\hline & IDf & 5.557 & & \\
\hline & $\mathrm{IDg}$ & 5.138 & & \\
\hline & IDh & 2.273 & & \\
\hline \multirow{3}{*}{$\begin{array}{l}\text { Japanese } \\
\text { Business System }\end{array}$} & JBSa & 1.179 & \multirow{3}{*}{0.448} & \multirow{3}{*}{0.483} \\
\hline & $\mathrm{JBSb}$ & 5.561 & & \\
\hline & JBSc & 8.689 & & \\
\hline \multirow{6}{*}{$\begin{array}{l}\text { Cultural } \\
\text { Openness }\end{array}$} & CULTa & 3.441 & \multirow{6}{*}{0.863} & \multirow{6}{*}{0.579} \\
\hline & CULTb & 4.105 & & \\
\hline & CULTc & 4.067 & & \\
\hline & CULTd & 3.864 & & \\
\hline & CULTe & 2.786 & & \\
\hline & CULTf & 2.027 & & \\
\hline
\end{tabular}

Notes: Bootstrapping results (i.e., 5,00 subsamples; no sign change option) 
Table 3: Descriptive Statistics

\begin{tabular}{|l|l|l|l|}
\hline Constructs & N & Average & Standard Deviation \\
\hline Job Satisfaction & 90 & 3.47 & 0.81 \\
\hline $\begin{array}{l}\text { Organizational } \\
\text { Identification }\end{array}$ & 88 & 3.45 & 0.76 \\
\hline $\begin{array}{l}\text { Japanese Business } \\
\text { System }\end{array}$ & 86 & 2.60 & 0.77 \\
\hline Cultural Openness & 90 & 3.98 & 0.68 \\
\hline
\end{tabular}

Table 4: Pearson Correlations

\begin{tabular}{|c|c|c|c|c|c|}
\hline \multicolumn{2}{|l|}{ Constructs } & \multirow{2}{*}{$\begin{array}{c}\text { Job } \\
\text { Satisfaction } \\
\\
1\end{array}$} & \multirow{2}{*}{$\begin{array}{c}\text { Organi-zation } \\
\text { al } \\
\text { Identification }\end{array}$} & \multirow{2}{*}{$\begin{array}{c}\text { Japanese } \\
\text { Business } \\
\text { System }\end{array}$} & \multirow{2}{*}{$\begin{array}{l}\text { Cultural } \\
\text { Openness }\end{array}$} \\
\hline Job Satisfaction & Pearson Correlation & & & & \\
\hline & Sig. (2-tailed) & & & & \\
\hline & $\mathrm{N}$ & 90 & & & \\
\hline \multirow{3}{*}{$\begin{array}{l}\text { Organizational } \\
\text { Identification }\end{array}$} & Pearson Correlation &, $603^{* *}$ & 1 & & \\
\hline & Sig. (2-tailed) & ,000 & & & \\
\hline & $\mathrm{N}$ & 88 & 88 & & \\
\hline \multirow{3}{*}{$\begin{array}{c}\text { Japanese } \\
\text { Business } \\
\text { System }\end{array}$} & Pearson Correlation &,$- 380^{\star *}$ &,$- 460^{\star *}$ & 1 & \\
\hline & Sig. (2-tailed) & ,000 & ,000 & & \\
\hline & $\mathrm{N}$ & 86 & 84 & 86 & \\
\hline \multirow{3}{*}{$\begin{array}{l}\text { Cultural } \\
\text { Openness }\end{array}$} & Pearson Correlation &, $250^{*}$ &, $254^{*}$ &,- 092 & 1 \\
\hline & Sig. (2-tailed) & ,018 & ,017 & ,401 & \\
\hline & $\mathrm{N}$ & 90 & 88 & 86 & 90 \\
\hline
\end{tabular}

**. Correlation is significant at the 0.01 level (2-tailed).

*. Correlation is significant at the 0.05 level (2-tailed). 
Table 5: Path Coefficients, Standard Deviations, and Significance Tests

\begin{tabular}{|l|l|l|l|}
\hline & Path Coefficient & $t$-Value & $p$-Value \\
\hline Organizational Identification to Job Satisfaction & $0.513^{\star \star \star}$ & 5.900 & 0.000 \\
\hline Japanese Business System to Job Satisfaction & $-0.227^{\star *}$ & 2.326 & 0.020 \\
\hline Cultural Openness to Job Satisfaction & 0.022 & 0.237 & 0.813 \\
\hline $\begin{array}{l}\text { Cultural Openness x Japanese Business } \\
\text { System to Job Satisfaction }\end{array}$ & $0.140^{\star}$ & 1.799 & 0.072 \\
\hline
\end{tabular}

DV: Job Satisfaction

Notes: Bootstrapping results (i.e., 5000 subsamples; no sign change option) are marked with asterisks according to the significance level.

$\star \star \star$ Significant at $1 \%$

**Significant at $5 \%$

*Significant at $10 \%$ 


\section{PLS-SEM-Model}

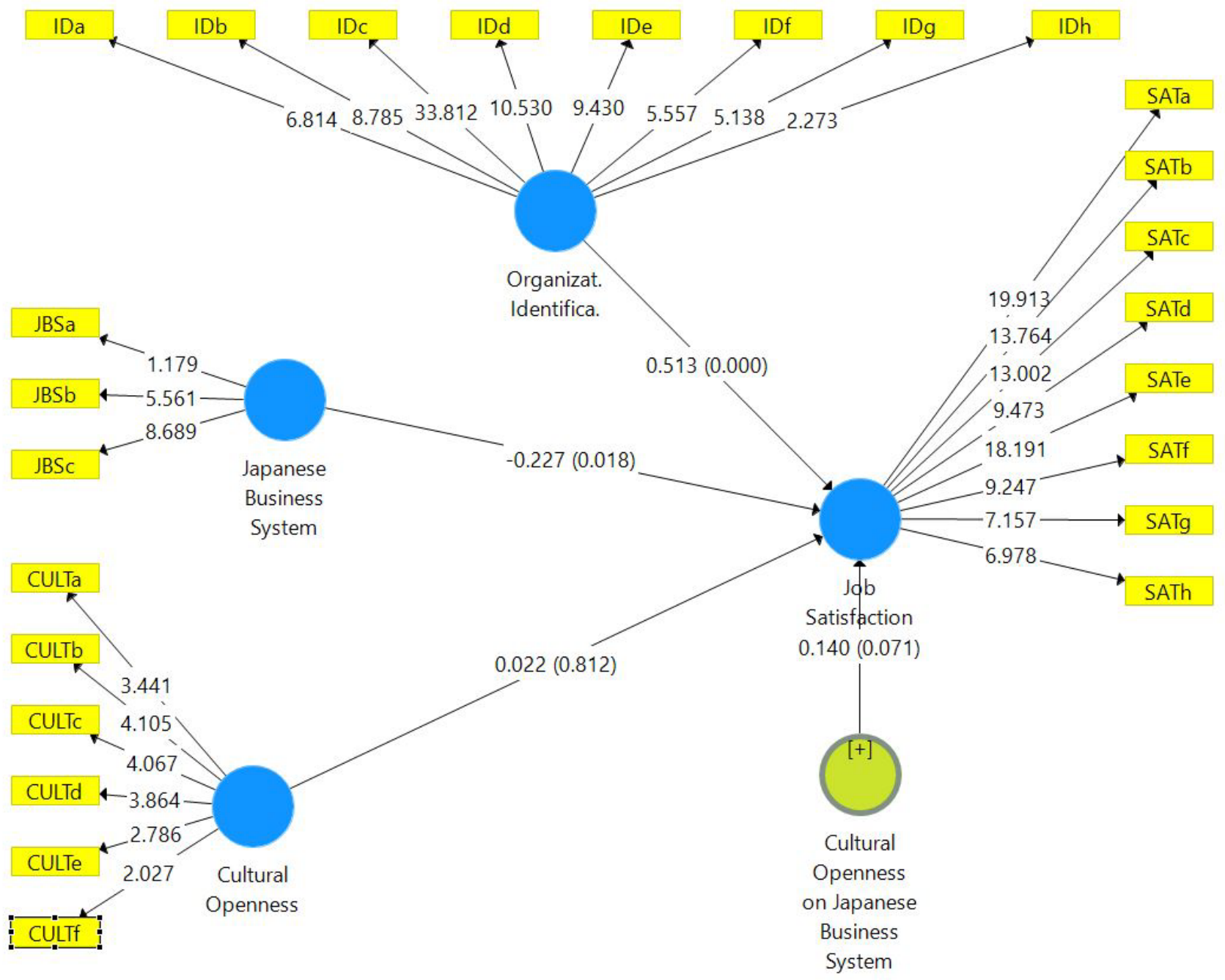

